\title{
PENGARUH KECERDASAN VERBAL LINGUISTIK TERHADAP HASIL BELAJAR PADA MATA PELAJARAN BAHASA INDONESIA
}

\section{THE INFLUENCE OF LINGUISTIC VERBAL INTELLIGENCE TOWARD THE RESULT OF INDONESIAN LANGUAGE}

\author{
Andi Halimah ${ }^{1}$, Ahmad Afif $^{2}$, Besse Ratu ${ }^{3}$ \\ ${ }^{1,2,3}$ Fakultas Tarbiyah dan Keguruan UIN Alauddin Makassar \\ ${ }^{1,2,}{ }^{3}$ Kampus II: Jalan H. M. Yasin Limpo Nomor 36 Samata-Gowa \\ Email: andi.halimah@uin-alauddin.ac.id ${ }^{1}$, ahmad.afiif@uin-alauddin.ac.id $^{2}$, \\ besse.ratu@gmail.com ${ }^{3}$
}

\begin{abstract}
Abstrak
Penelitian ini bertujuan untuk mengetahui kecerdasan verbal linguistik, untuk mengetahui hasil belajar bahasa Indonesia, dan untuk mengetahui pengaruh kecerdasan verbal linguistik terhadap hasil belajar bahasa Indonesia peserta didik kelas V MIN Batu Pitumpanua Kabupaten Wajo. Penelitian ini adalah penelitian kuantitatif, jenis penelitian ini adalah penelitian ex-postfacto. Populasi dalam penelitian ini adalah seluruh siswa kelas V MIN Batu Pitumpanua Kabupaten Wajo yang berjumlah 60 orang, sedangkan sampel penelitian adalah seluruh populasi yaitu peserta didik kelas V MIN Batu Pitumpanua Kabupaten Wajo. Instrumen yang digunakan dalam penelitian ini adalah skala kecerdasan verbal linguistik dan dokumentasi. Teknik analisis data yang digunakan adalah analisis statistik deskriptif dan analisis statistika inferensial uji regresi sederhana. Berdasarkan hasil analisis statistik deskriptif, kecerdasan verbal linguistik diperoleh nilai rata-rata 86,9 , diperoleh nilai terendah 57 , dan nilai tertinggi 102 dan berada pada kategori sedang dengan persentase 55\%. Hasil belajar bahasa Indonesia diperoleh nilai rata-rata 88,7 , nilai terendah 80 , dan nilai tertinggi 95 dan berada pada kategori tinggi dengan persentase 53,3\%. Adapun hasil analisis statistik inferensial dengan uji regresi sederhana diperoleh sig < $\alpha(0,024<0,05)$. Hal ini berarti Ho ditolak dan Ha diterima yang berarti terdapat pengaruh yang positif antara kecerdasan verbal linguistik terhadap hasil belajar peserta didik kelas V MIN Batu Pitumpanua Kabupaten Wajo.
\end{abstract}

Kata Kunci: Kecerdasan Verbal Linguistik, Hasil Belajar

\section{Abstract}

This study aims to determine verbal linguistic intelligence, to find out the results of learning Indonesian, and to determine the effect of linguistic verbal intelligence on the learning outcomes of Indonesian students in class V MIN Batu Pitumpanua Wajo Regency. This study is quantitative research, the type of research is ex-postfacto research. The population in this study were all students of class $V$ MIN Batu Pitumpanua district Wajo, amounting to 60 people, while the study sample was the entire population, namely class V students of MIN Batu Pitumpanua, Wajo Regency. The instrument used in this study is the verbal intelligence linguistic scale and documentation. The data analysis technique used is descriptive statistical analysis and inferential statistical analysis simple regression test. Based on the results of descriptive statistical analysis, linguistic verbal intelligence obtained an average value of 86.9, obtained the lowest value of 57, and the highest score of 102 and was in the medium category with a percentage of 55\%. The results of learning Indonesian obtained an average value of 88.7, the lowest score was 80, and the highest score was 95 and was in the high category with a percentage of $53.3 \%$. The results of inferential statistical analysis with a simple regression test are obtained sig $<\alpha(0.024<0.05)$. This means that Ho is rejected and Ha is accepted, which means there is a positive influence between 
linguistic verbal intelligence on learning outcomes of class V students of MIN Batu Pitumpanua, Wajo Regency.

Keywords: Linguistic Verbal Intelligence, Learning Outcomes

\section{Pendahuluan}

Pendidikan merupakan sarana yang paling penting dalam menguatkan dan meningkatkan potensi yang terdapat dalam diri setiap individu. Menurut UndangUndang No. 20 Tahun 2003 tentang Sistem Pendidikan Nasional, pada pasal 1 ayat 1 bahwa pendidikan adalah usaha sadar dan terencana untuk mewujudkan suasana belajar dan proses pembelajaran agar peserta didik secara aktif mengembangkan potensi dirinya untuk memiliki kekuatan spiritual keagamaan, pengendalian diri, kepribadian, kecerdasan akhlak mulia, serta keterampilan yang diperlukan dirinya, masyarakat bangsa dan negara (Ramayulis, 2012).

Pendidikan juga hakikatnya berlangsung dalam suatu proses. Proses itu berupa transformasi nilai-nilai pengetahuan, teknologi, dan keterampilan. Penerima proses adalah anak atau peserta didik yang sudah tumbuh dan berkembang menuju ke arah pendewasaan kepribadian dan penguasaan pengetahuan. Selain itu, pendidikan merupakan proses budaya untuk meningkatkan harkatdan martabat manusia yang diperoleh melalui proses yang panjang dan berlangsung sepanjang kehidupan.

Pendidikan tidak terlepas dari proses pembelajaran sebagai alat untuk mengukur tingkat keberhasilan pendidikan itu sendiri. Dalam proses pembelajaran pencapaian tujuan sangat dipengaruhi oleh bagaimana proses belajar yang dialami oleh peserta didik. Oleh karena itu, kegiatan belajar merupakan kegiatan yang paling penting demi terwujudnya pembelajaran yang baik dan efisien.

Menurut Deni Kurniawan (2014), belajar itu sebagai proses aktif internal individu dimana melalui pengalamannya berinteraksi dengan lingkungan menyebabkan terjadinya perubahan tingkah laku yang relatif permanen. Belajar adalah proses usaha yang dilakukan seseorang untuk memperoleh suatu perubahan yang barusebagai hasil dari pengalamannya sendiri dalam interaksi dengan lingkungannya. Perubahan yang dimaksud adalah perubahan yang terjadi secara sadar dan tertuju untuk memperoleh sesuatu yang lebih baik dari sebelumnya (Sugiyanti, 2012).

Dalam proses pembelajaran setiap peserta didik memiliki kecerdasan masingmasing yang harus dikembangkan. Salah satu kecerdasan yang dimiliki oleh peserta didik adalah kecerdasan verbal linguistik. Kecerdasan verbal linguistik adalah kecerdasan dalam mengolah kata. dan merupakan kecerdasan paling universal diantara ketujuh kecerdasan dalam teori kecerdasan ganda (Armstrong, 2002). Kecerdasan verbal linguistik adalah kecerdasan dalam mengolah kata atau kemampuan menggunakan kata secara efektif baik secara lisan maupun tertulis. Orang yang cerdas dalam bidang ini dapat berargumentasi, meyakinkan orang, menghibur, atau mengajar dengan efektif lewat kata-kata yang diucapkan (Sujiono \& Sujiono, 2010). Kecerdasan verbal linguistik adalah pemahaman terhadap fonologi, sintaksis dan semantik bahasa, dan penggunaan pragmatisnya untuk meyakinkan orang lain dengan tindakan, membantu orang untuk mengingat informasi, menjelaskan atau mengomunikasikan pengetahuan, atau merenungkan bahasa itu sendiri. Contohnya mencakup pendongeng, orator, penyair, editor, dan novelis (Armstrong, 2014).

Berdasarkan hal tersebut di atas dapat dinyatakan bahwa kecerdasan memegang peranan penting dalam mencapai keberhasilan. Kemampuan belajar peserta didik, serta 
kemampuan guru mengetahui dan memanfaatkan kecerdasan verbal linguistik peserta didik akan tumbuh dalam mencapai tujuan pembelajaran. Sehingga tercapainya tujuan pembelajaran yang diinginkan sesuai dengan indikator pencapaian.

Kecerdasan yang dimiliki peserta didik dalam hal ini yang menjadi salah satu faktor yang mempengaruhi hasil belajar peserta didik. Hasil belajar berupa perubahan perilaku dan pribadi yang bersifat fungsional-struktural, material substansial dan behavioral, dalam kawasan kognitif, afektif, dan psikomotor (Aisyah, 2015). Hasil belajar secara sederhana, adalah kemampuan yang diperoleh anak setelah melalui kegiatan belajar karena belajar itu sendiri merupakan suatu proses dari seseorang yang berusaha untuk memperoleh suatu bentuk perubahan perilaku yang relatif menatap. Dalam kegiatan pembelajaran atau kegiatan instruksional, biasanya guru menetapkan tujuan belajar. Anak yang berhasil dalam belajar adalah yang berhasil mencapai tujuan pembelajaran atau tujuan instruksional (Susanto, 2013). Hasil belajar peserta didik hakikatnya adalah perubahan tingkah laku sebagai hasil belajar yang lebih luas mencakup bidang kognitif, afektif, dan psikomotorik. Bidang kognitif terdiri dari tingkat pengetahuan siswa, bidang afektif tentang sikap dan perilaku siswa, dan bidang psikomotor yaitu tentang keterampilan siswa. untuk mengetahui hasil belajar peserta didik maka digunakan alat ukur berupa tes hasil belajar.

Berdasarkan hasil observasi yang dilakukan di MIN Batu Pitumpanua Kabupaten Wajo terdapat beberapa permasalahan dalam mata pelajaran bahasa Indonesia di antaranya adalah hasil belajar peserta didik masih rendah. Hal ini banyak peserta didik yang memiliki nilai di bawah KKM (Kriteria Ketuntasan Minimum).

Berdasarkan penelitian yang dilakukan oleh Kamrida (2017) yang menyatakan bahwa hasil analisis statistik deskriptif kecerdasan verbal-linguistik diperoleh nilai ratarata 89,79 berada pada kategori sedang, 31 responden ( $84 \%$ ) berada pada kategori sedang, dan 6 responden (16\%) berada pada kategori tinggi. Untuk analisis deskriptif hasil belajar diperoleh nilai rata-rata 75,81 berada pada kategori tinggi, dari 37 responden. 7 responden (18\%) berada pada kategori sedang dan 30 responden $(81 \%)$ berada pada kategori tinggi. Adapun hasil analisis inferensial dengan uji regresi sederhana pengaruh kecerdasan verbal-linguistik terhadap hasil belajar yaitu nilai signifikansi (Sig.) sebesar 0,003 lebih kecil dari < probabilitas 0,05, maka $\mathrm{H}_{0}$ ditolak dan $\mathrm{H}_{1}$ diterima, yang berarti bahwa ada pengaruh kecerdasan verbal-linguistik terhadap hasil belajar.

Berdasarkan uraian di atas, maka peneliti termotivasi untuk melakukan penelitian yang berjudul: "Pengaruh Kecerdasan Verbal Linguistik terhadap Hasil Belajar Bahasa Indonesia Peserta Didik Kelas V MIN Batu Pitumpanua Kabupaten Wajo".

\section{Metode Penelitian}

Penelitian ini adalah penelitian kuantitatif dan jenis penelitian yang digunakan adalah penelitian Ex-post facto. Lokasi penelitian bertempat di MIN Batu Pitumpanua Jalan Tocamming No. 33 Kelurahan Siwa Kecamatan Pitumpanua Kabupaten Wajo Provinsi Sulawesi Selatan. Desain penelitian ini adalah paradigma sederhana dengan satu variabel independen dan satu variabel dependent sebagaimana ditunjukkan pada gambar berikut ini: 


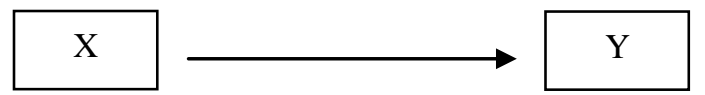

Gambar 1. Desain penelitian paradigma sederhana

Keterangan

$\mathrm{X}$

: Kecerdasan Verbal Linguistik

$\mathrm{Y} \quad$ : Hasil Belajar Bahasa Indonesia

$\longrightarrow \quad$ : Pengaruh Variabel X dengan Variabel Y

Dalam penelitian ini yang menjadi populasi adalah seluruh peserta didik kelas V MIN Batu Pitumpanua Kabupaten Wajo sebayak 60 peserta didik. Sampel pada penelitian ini berjumlah 60 responden atau dengan kata lain jumlah sampel yang akan diteliti sama dengan jumlah populasi. Instrumen yang digunakan dalam penelitian ini adalah skala psikologi dan dokumen. Teknik analisis data yang digunakan adalah analisis statistik deskriptif dan analisis statistika inferensial uji regresi sederhana.

\section{Hasil dan Pembahasan}

\subsection{Hasil}

Data hasil penelitian ini adalah data yang diperoleh dari kecerdasan verbal linguistik terhadap hasil belajar pada mata pelajaran bahasa Indonesia peserta didik kelas V MIN Batu Pitumpanua Kabupaten Wajo. Berikut ini hasil yang diperoleh setelah melakukan penelitian:

Tabel 1. Kategori Kecerdasan Verbal Linguistik Peserta Didik Kelas V MIN Batu Pitumpanua Kabupaten Wajo

\begin{tabular}{cccc}
\hline Interval & Frekuensi & Persentase & Kategori \\
\hline $\mathrm{X}<70$ & 1 & $1,6 \%$ & Rendah \\
\hline $70<\mathrm{X}<90$ & 33 & $55 \%$ & Sedang \\
\hline $90<\mathrm{X}$ & 26 & $43,3 \%$ & Tinggi \\
\hline Total & 60 & $99,9 \%$ & - \\
\hline
\end{tabular}

Berdasarkan tabel 1 menunjukkan bahwa 1,6\% kecerdasan verbal linguistik peserta didik berada pada kategori rendah dengan jumlah frekuensi 1 peserta didik, 55\% berada pada kategori sedang dengan jumlah frekuensi 33 peserta didik, dan 43,3\% berada pada kategori tinggi dengan jumlah frekuensi 26 peserta didik. Berdasarkan data tersebut dapat disimpulkan bahwa, peserta didik kelas V MIN Batu Pitumpanua Kabupaten Wajo memiliki kecerdasan verbal linguistik yang relatif sedang. Sehingga dapat disimpulkan bahwa peserta didik kelas V MIN Batu Pitumpanua Kabupaten Wajo termasuk dalam kategori sedang dengan persentase $55 \%$.

Tabel 2. Kategori Hasil Belajar Peserta Didik Kelas V MIN Batu Pitumpanua Kabupaten Wajo

\begin{tabular}{cccc}
\hline Interval & Frekuensi & Persentase & Kategori \\
\hline $\mathrm{X}<74,51$ & 0 & $0 \%$ & Rendah \\
\hline $74,51<\mathrm{X}<89$ & 28 & $46,6 \%$ & Sedang \\
\hline $89<\mathrm{X}$ & 32 & $53,3 \%$ & Tinggi \\
\hline Total & 60 & $100 \%$ & - \\
\hline
\end{tabular}


Berdasarkan tabel 2 menunjukkan bahwa $0 \%$ kecerdasan verbal linguistik peserta didik berada pada kategori rendah dengan jumlah frekuensi 0 peserta didik, 46,6\% berada pada kategori sedang dengan jumlah frekuensi 28 peserta didik, dan $53,3 \%$ berada pada kategori tinggi dengan jumlah frekuensi 32 peserta didik. Berdasarkan data tersebut, dapat disimpulkan bahwa peserta didik kelas V MIN Batu Pitumpanua Kabupaten Wajo memiliki hasil belajar yang relatif tinggi. Sehingga dapat disimpulkan bahwa peserta didik kelas V MIN Batu Pitumpanua Kabupaten Wajo termasuk dalam kategori tinggi dengan persentase 53,3\%. linearitas.

Pengujian dasar-dasar analisis yang dilakukan meliputi uji normalitas, uji

Tabel 3. Hasil Uji Normalitas

\begin{tabular}{cccc}
\hline Variabel & K-SZ & Sig & Keterangan \\
\hline Kecerdasan Verbal Linguistik (X) & 1,150 & 0,142 & Normal \\
\hline Hasil Belajar (Y) & 1,707 & 0,006 & Normal \\
\hline
\end{tabular}

Berdasarkan uji normalitas dengan menggunakan uji Kolmogorov-Smirnov Z pada tabel 3, diperoleh nilai K-SZ untuk variabel X (Kecerdasan Verbal Linguistik) sebesar 1,150, dan K-SZ untuk variabel Y (Hasil Belajar) sebesar 1,707. Nilai Asymp.Sig. (2-tailed) untuk variabel $\mathrm{X}$ sebesar 0,142, dan variabel $\mathrm{Y}$ sebesar 0,06. Hasil yang diperoleh lebih besar dari 0,05 $(>0,05)$ maka dapat disimpulkan data berdistribusi normal dan dapat dilanjutkan dengan analisis regresi.

Tabel 4. Hasil Uji Linearitas

\begin{tabular}{cccc}
\hline Korelasi & Deviasi & Sig & Keterangan \\
\hline XY & 0,069 & 0,012 & Linear \\
\hline
\end{tabular}

Berdasarkan pada tabel 4, diperoleh hasil uji linearitas kecerdasan verbal linguistik terhadap hasil belajar diperoleh nilai sig. 0,012<0,05 sehingga dapat disimpulkan bahwa antara kecerdasan verbal linguistik terhadap hasil belajar bahasa Indonesia memiliki hubungan yang linier.

Selanjutnya dilakukan analisis regresi sederhana untuk mengetahui pengaruh antara kecerdasan verbal linguistik terhadap hasil belajar peserta didik kelas V MIN Batu Pitumpanua Kabupaten Wajo.

Berdasarkan hasil uji regresi yang dilakukan, konstanta dan koefisien persamaan diperoleh dari kolom $\mathrm{B}$, diperoleh persamaan regresi: $\mathrm{Y}=78.571+0,114 \mathrm{X}$.

Pengujian simultan merupakan pengujian secara bersama-sama koefisien variabel kecerdasan verbal linguistik terhadap hasil belajar bahasa Indonesia.

Tabel 4. Hasil Analisis Regresi Sederhana

\begin{tabular}{cccc}
\hline $\mathrm{R}$ & $\mathrm{R}^{2}$ & $\mathrm{~F}$ & $\mathrm{Sig}$ \\
\hline 0,290 & 0,084 & 5.339 & 0,024 \\
\hline
\end{tabular}

Berdasarkan hasil analisis data yang dilakukan, dapat disimpulkan bahwa terdapat pengaruh positif yang signifikan (sig $<0,05)$ antara kecerdasan verbal linguistik terhadap hasil belajar peserta didik kelas V MIN Batu Pitumpanua Kabupaten Wajo. 


\subsection{Pembahasan}

Berdasarkan hasil analisis data dengan menggunakan statistik deskriptif kecerdasan verbal linguistik dapat dikemukakan bahwa dari 60 peserta didik yang dijadikan sebagai sampel penelitian, diperoleh skor kecerdasan verbal linguistik tertinggi sebesar 102 dan terendah 57. Rata-rata skor (mean) sebesar 86,9 dan standar deviasi sebesar 266,74. Berdasarkan analisis data dan pengkategorian kecerdasan verbal linguistik peserta didik kelas V MIN Batu Pitumpanua Kabupaten Wajo, menunjukkan bahwa 55\% berada pada kategori sedang. Hal ini menunjukkan bahwa kecerdasan verbal linguistik peserta didik baik.

Hasil analisis data dengan menggunakan statistik deskriptif dapat dikemukakan bahwa dari 60 peserta didik yang dijadikan sampel penelitian, diperoleh nilai tertinggi 95 dan nilai terendah 80 Rata-rata skor (mean) sebesar 88,7 dan standar deviasi sebesar 14,19 . Hasil penelitian menunjukkan bahwa terdapat $0 \%$ berada dalam kategori rendah, 28 orang 46,6\% yang berada dalam kategori sedang, dan 32 orang 53,3\% berada dalam kategori tinggi. Jika dilihat dari nilai rata-rata yang diperoleh sebesar 86,9 apabila dimasukkan dalam kategori kecerdasan verbal linguistik maka nilai tersebut berada pada kategori sedang dengan persentase 55\%, maka rata-rata hasil belajar peserta didik kelas V MIN Batu Pitumpanua Kabupaten Wajo berada pada kategori tinggi dengan frekuensi 33 dan persentasenya $53,3 \%$.

Berdasarkan analisis data dan pengkategorian hasil belajar peserta didik kelas $\mathrm{V}$ MIN Batu Pitumpanua Kabupaten Wajo, menunjukkan bahwa 53,3\% berada pada kategori tinggi.

Berdasarkan uji analisis regresi sederhana, hasil penelitian menunjukkan bahwa terdapat pengaruh yang signifikan antara kecerdasan verbal linguistik terhadap hasil belajar peserta didik MIN Batu Pitumpanua Kabupaten Wajo. Hal ini tercermin dari hasil analisis dengan menggunakan analisis regresi sederhana diperoleh persamaan $\mathrm{Y}=$ $78.571+0,114 X$. Berdasarkan uji hipotesis dengan nilai $\mathrm{P}(\mathrm{P}=0,024<0,05)$.

Kecerdasan verbal linguistik merupakan satu dari delapan jenis kecerdasan yang dimiliki oleh setiap individu. Hal ini berdasarkan teori Multiple Intelligences yang diperkenalkan tahun 1983 oleh Howard Gardner dalam Thomas Amstrong. Kecerdasan atau yang sering disebut dengan Intelligences dapat ditingkatkan dan berkembang sepanjang sejarang hidup seseorang. Menurut Howard Gadner, kecerdasan adalah kemampuan untuk memecahkan masalah atau menciptakan sesuatu yang bernilai bagi budaya tertentu (Efendi, 2005). Kecerdasan tersebut dapat digunakan dalam waktu yang bersamaan dan cenderung melengkapi satu sama lain.

Kecerdasan verbal linguistik adalah kemampuan untuk menggunakan bahasa lisan maupun tulisan secara tepat dan akurat. Menggunakan kata merupakan cara utama untuk berpikir dan menyelesaikan masalah bagi orang yang memiliki kecerdasan ini. Mereka cenderung mempunyai keterampilan reseptif (input) auditori dan produktif (output) verbal yang sangat baik (Yaumi \& Ibrahim, 2013). Kecerdasan verbal linguistik adalah kemampuan seseorang untuk menggunakan bahasa dan kata-kata, baik secara tertulis maupun lisan, dalam berbagai bentuk yang berbeda untuk mengekspresikan gagasan-gagasannya (Uno \& Umar, 2010).

Seorang anak yang memiliki kecerdasan bahasa yang tinggi akan mampu menceritakan cerita lucu dan adegan lelucon, menulis lebih baik dari rata-rata anak lain yang memiliki usia yang sama, memori tentang nama, tempat tinggal, dan informasi lain lebih baik dari anak pada umumnya. Senang terhadap permainan kata, menyukai baca buku, menghargai sajak, dan permainan kata-kata. Suka mendengar cerita tanpa melihat 
buku, mengomunikasikan pikiran, perasaan dan ide-ide dengan baik, serta mendengarkan dan merespon bunyi-bunyi irama. Kecerdasan verbal linguistik meliputi empat aspek yaitu sebagai berikut: aspek mendengar, berbicara, membaca, dan menulis.

Di Madrasah Ibtidaiyah pembelajaran mata pelajaran bahasa Indonesia memiliki standar kompetensi mendengarkan, berbicara, membaca, dan menulis. Kompetensi mendengar berkaitan dengan kemampuan peserta didik memahami cerita tentang suatu peristiwa dan cerita pendek anak yang disampaikan secara lisan. Kompetensi berbicara berhubungan kemampuan peserta didik mengungkapkan pikiran dan perasaan secara lisan dalam diskusi dan bermain drama. Kompetensi membaca berkaitan kemampuan peserta didik memahami teks dengan membaca sekilas, membaca memindai, dan membaca cerita anak. Kompetensi menulis merupakan kemampuan peserta didik mengungkapkan pikiran, perasaan, informasi, dan fakta secara tertulis dalam bentuk ringkasan, dan puisi bebas. Materi pelajaran di kelas V Madrasah Ibtidaiyah meliputi: mendengar cerita pendek, membaca memindai, menulis puisi, membaca cerita, meringkas isi buku, dan membaca cerita anak.

Untuk mencapai hasil belajar peserta didik dalam mata pelajaran bahasa Indonesia diperlukan bakat dan kemampuan peserta didik dalam bidang bahasa, kemampuan yang dimiliki adalah kecerdasan verbal linguistik. Hasil penelitian ini menunjukkan bahwa kecerdasan verbal linguistik berpengaruh terhadap hasil belajar bahasa Indonesia peserta didik kelas V MIN Batu Pitumpanua Kabupaten Wajo.

\section{Kesimpulan}

Berdasarkan hasil analisis data dan pembahasan, maka dapat disimpulkan bahwa berdasarkan data yang di peroleh dari hasil penelitian terhadap 60 orang peserta didik mengenai kecerdasan verbal linguistik peserta didik kelas V MIN Batu Pitumpanua Kabupaten Wajo berada pada kategori sedang sebanyak 33 orang dengan persentase $55 \%$. Selain itu, berdasarkan data yang diperoleh dari hasil penelitian terhadap 60 orang peserta didik mengenai dokumentasi hasil belajar peserta didik pada mata pelajaran bahasa Indonesia kelas V MIN Batu Pitumpanua Kabupaten Wajo berada pada kategori tinggi sebanyak 32 orang dengan persentase 53,3\%. Selain itu, terdapat pengaruh yang signifikan kecerdasan verbal linguistik terhadap hasil belajar pada mata pelajaran bahasa Indonesia peserta didik kelas V MIN Batu Pitumpanua Kabupaten Wajo. Hal ini dilihat dari hasil analisis menggunakan uji regresi membuktikan bahwa persamaan regresi diperoleh $\mathrm{Y}=78.571+0,114 \mathrm{X}$. Dari hasil uji signifikan, diperoleh nilai signifikan sebesar 0,024 dimana nilai signifikan $>0,05(0,024<0,05)$, maka Ho ditolak. Jadi dapat disimpulkan bahwa ada pengaruh yang signifikan antara kecerdasan verbal linguistik terhadap hasil belajar.

\section{Daftar Pustaka}

Aisyah, S. (2015). Perkembangan Peserta Didik dan Bimbingan Belajar. Yogyakarta: Deepublish.

Armstrong, T. (2002). 7 Kinds Of Smart. Jakarta: Gramedia Pustaka Utama.

Armstrong, T. (2014). Kecerdasan Jamak dalam Membaca dan Menulis. Jakarta: Permata Putri Media.

Efendi, A. (2005). Revolusi Kecerdasan Abad 21. Bandung: Alfabeta. 
Kamrida. (2017). Pengaruh Kecerdasan Verbal-Linguistik terhadap Hasil Belajar IPA Terpadu Peserta Didik Kelas VIII MTs Negeri 1 Kota Makassar. UIN Alauddin Makassar. Retrieved from http://repositori.uinalauddin.ac.id/8388/1/KAMRIDA.pdf

Kurniawan, D. (2014). Pembelajaran Terpadu Tematik (Teori, Praktik, dan Penilaian). Bandung: Alfabeta.

Ramayulis. (2012). Ilmu Pendidikan Islam. Jakarta: Kalam Mulia.

Sugiyanti. (2012). Peningkatkan Prestasi Belajar Menggunakan Alat-Alat Ukur melalui Penggunaan Media Komputer. Jurnal Penelitian Pendidikan, 29(1), 53-59. Retrieved from https://media.neliti.com/media/publications/125072-IDpeningkatkan-prestasi-belajar-menggunaka.pdf

Sujiono, Y. N., \& Sujiono, B. (2010). Bermain Kreatif Berbasis Kecerdasan Jamak. Jakarta: Indeks.

Susanto, A. (2013). Teori Belajar \& Pembelajaran di Sekolah Dasar. Jakarta: Fajar Interpretama Mandiri.

Uno, H. B., \& Umar, M. K. (2010). Mengelola Kecerdasan dalam Pembelajaran: Sebuah Konsep Pembelajaran Berbasis Kecerdasan. Jakarta: Bumi Aksara.

Yaumi, M., \& Ibrahim, N. (2013). Pembelajaran Berbasis Kecerdasan Jamak (Multiple Intelligences) Mengidentifikasi dan mengembangakan Multitalenta Anak. Jakarta: Prenadamedia Group. 